\title{
A study on effects of personal characteristics on organizational commitment
}

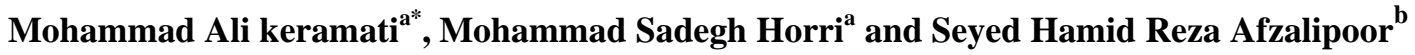

${ }^{a}$ Assistant Professor of Public Administration, Faculty of Management, Islamic Azad University, Arak, Iran ${ }^{b}$ Master of Public Administration, Islamic Azad University, Arak, Iran

\begin{tabular}{|c|c|}
\hline ART I C LE I NFO & AB S T RACT \\
\hline $\begin{array}{l}\text { Article history: } \\
\text { Received March 25, } 2012 \\
\text { Received in revised format } \\
\text { 25 September } 2012 \\
\text { Accepted } 8 \text { October } 2012 \\
\text { Available online } \\
\text { October } 142012 \\
\text { Keywords: } \\
\text { Organizational commitment } \\
\text { University employee } \\
\text { Job stability }\end{array}$ & $\begin{array}{l}\text { Organizational commitment is an essential part of business development especially in } \\
\text { educational system. In this paper, we study the relationship between six personal } \\
\text { characteristics of employees of Azad University in province of Arak, Iran. The proposed study } \\
\text { designs and distributes a questionnaire among experts who are involved in education systems. } \\
\text { The population of this survey includes } 900 \text { employees who are enrolled in educational as well } \\
\text { as administration levels and chooses a sample of } 269 \text { people for the survey. The questionnaire } \\
\text { consists of different questions in Likert scale and there are six independent variables including } \\
\text { age, gender, educational background, marital status, job experience and salary. We study the } \\
\text { relationship of these six items with organization commitment. The results of our survey indicate } \\
\text { that marital status is the most influential factor on organizational commitment followed by } \\
\text { educational background and job experience. Based on the results of this survey, we can } \\
\text { conclude that those employees who could get more experience and maintain a good educational } \\
\text { background will more likely to stay with a firm than young employees. }\end{array}$ \\
\hline
\end{tabular}

\section{Introduction}

Organizational commitment plays an important role for the stability of educational system. Highly committed university professors could contribute more in terms of teaching or research achievement. There are literally many studies associated with organizational commitment and its relationship with various personal characteristics. According to Antonacopoulou (2000), employees who have strong commitment to organization spend more time on their job and perform their jobs with more discipline. McCabe and Garavan (2008) reported that commitment was the most influential item for the success of a firm. Freund and Carmeli (2003) reported that a highly committed person increase organizations' efficiency more significantly. Aube et al. (2007) backed this idea and suggested that increasing organizational commitment through having people with strong motivations for long-term positions. There are many reasons to support this argument. First, there are various evidences, which * Corresponding author.

E-mail addresses: mohammadalikeramati@yahoo.com (M. A. Keramati) 
indicate that organizational commitment had positive relationship with job satisfaction, job performance and employee's leave. Second, organizational commitment was relatively a new concept, which was different from job satisfaction (Jaramillo \& Nixson, 2005). Finally, commitment represents citizenship behavior because it influences this factor, substantially.

According to Pleck et al. (1980), significant amount of work, afternoon shift work, working conditions with no flexibility, the lack of ability to leave the job in emergency conditions are among the most influential factors in work-life issues. Khan et al. (1964) reported that work pressure plays an essential impact on creating conflict on work-life policy. In other words, when such conflict occurs people with different personalities may have serious problems (Katz et al.,1978; Schwartz, 1996; Pleck et al., 1980).

Nazeri et al. (2012) analyzed the role of the staff's wellbeing stated as independent variable and the work locus of control as the moderator factor associated with the organizational commitment and the staff's wellbeing based on the implementation of regression technique. They concentrated on one's capability to forecast the staff's wellbeing and investigated the impacts of the work locus of control as a moderator on the organizational commitment. Their results suggested that the staff's wellbeing could have a negative relationship with the continuance commitment and a positive relationship with the normative commitments. In addition, the effect of the work locus of control, as moderator, on the relationship between the staff's wellbeing and their organizational commitment relational and had some necessities.

Mirabizadeh and Gheitasi (2012) performed an investigation on organizational citizenship behavior (OCB) as an important factor on improving the efficiency of organizations. They investigated the relative importance of OCB in various universities located in the province of Ilam, Iran. There are four hypotheses associated with this survey and the results indicated that educational opportunities, work-life policy, empowerment activities had strong positive relationship on organizational commitment and organizational commitment impacted organizational citizenship behavior, accordingly.

Bahramzadeh and Khosroabadi (2012) presented a study in one of privately held universities located in city of Bojnourd, Iran. The proposed study selected a sample size 145 out of 236 people and used Pearson correlation test to analyze the findings. The proposed model of the paper confirmed that there was a positive and meaningful relationship between these two components when the level of significance was set to five percent. The results of this survey also disclosed that while ethical commitment and normative played important role on knowledge sharing, continuity had no significant effect on knowledge sharing within organization. The other observation is that while gender and age had no impact on knowledge sharing, higher educational background was an important factor on knowledge sharing.

Naderi Anari (2012) investigated the relationship between emotional intelligence and job satisfaction as well as emotional intelligence and organizational commitment, and between job satisfaction and organizational commitment among high-school English teachers. The results of their study indicated that there was a positive significant relationship between emotional intelligence and job satisfaction and organizational commitment, and between job satisfaction and organizational commitment. Naderi Anari reported that there was no significant difference among high-school English teachers of various genders and ages concerning their job satisfaction and organizational commitment. The results can help teachers and organizations in enhancing the job satisfaction and organizational commitment of teachers.

In this paper, we present an empirical investigation on relationship between personal characteristics and organizational commitment. The organization of this paper first presents details of the sampling and hypotheses in section 2 and section 3 presents details of findings. Finally, concluding remarks are given in the last to summarize the contribution of the paper. 


\section{The proposed study}

The proposed study of this paper considers the following hypotheses,

1. There is a meaningful relationship between age and organizational commitment.

2. There is a meaningful relationship between gender and organizational commitment.

3. There is a meaningful relationship between educational background and organizational background.

4. There is a meaningful relationship between marital status and organizational commitment.

5. There is a meaningful relationship between job experience and organizational commitment.

6. There is a meaningful relationship between wages and organizational commitment.

In this study, they considered the relationship between different job as well as personal characteristics and organizational commitment.

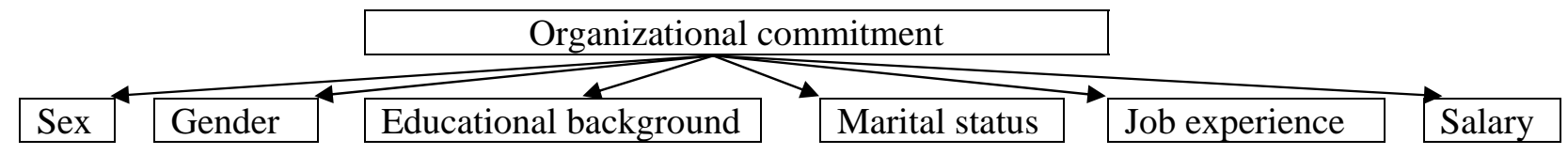

Fig. 1. The proposed model of the paper

The proposed study of this paper uses the following formula to calculate the minimum number of sample size,

$n=\frac{N \times z_{\alpha / 2}^{2} \times p \times q}{\varepsilon^{2} \times(N-1)+z_{\alpha / 2}^{2} \times p \times q}$,

where $N$ is the population size, $p=1-q$ represents the yes/no categories, $z_{\alpha / 2}$ is CDF of normal distribution and finally $\varepsilon$ is the error term. Since we have $p=0.5, z_{\alpha / 2}=1.96$ and $N=900$, the number of sample size is calculated as $n=269$. The proposed study of this paper uses Pearson correlation ratio between organizational commitment and other independent factors.

\section{The results}

In this section, we present details of our findings on the relationship between organizational commitment and other six factors.

\subsection{Age and organizational commitment}

The first hypothesis of this paper is associated with the effects of age on organizational commitment and the results are summarized in Table 1.

\section{Table 1}

Pearson correlation test between age and organizational commitment

\begin{tabular}{llllll}
\hline $\begin{array}{l}\text { Independent } \\
\text { variable }\end{array}$ & $\begin{array}{l}\text { Dependent } \\
\text { variable }\end{array}$ & $\begin{array}{l}\text { Level of } \\
\text { significance }\end{array}$ & P-value & $\begin{array}{l}\text { Pearson canonical } \\
\text { correlation }\end{array}$ & $\begin{array}{l}\text { Results of } \\
\text { hypothesis }\end{array}$ \\
\hline Age & $\begin{array}{l}\text { Organizational } \\
\text { commitment }\end{array}$ & 0.05 & 0.007 & 0.446 & Confirmed \\
\hline
\end{tabular}

As we can observe from the results of Table 1, there is relatively strong relationship between age and organizational commitment when the level of significance is five or even one percent. The positive 
sign shows that as employees are aging they tend to have better commitment towards their organization.

\subsection{Gender and organizational commitment}

The second hypothesis of this paper is associated with the effects of gender on organizational commitment and the results are summarized in Table 2.

\section{Table 2}

Pearson correlation test between gender and organizational commitment

\begin{tabular}{llllll}
\hline $\begin{array}{l}\text { Independent } \\
\text { variable }\end{array}$ & $\begin{array}{l}\text { Dependent } \\
\text { variable }\end{array}$ & $\begin{array}{l}\text { Level of } \\
\text { significance }\end{array}$ & P-value & $\begin{array}{l}\text { Pearson canonical } \\
\text { correlation }\end{array}$ & $\begin{array}{l}\text { Results of } \\
\text { hypothesis }\end{array}$ \\
\hline Gender & $\begin{array}{l}\text { Organizational } \\
\text { commitment }\end{array}$ & 0.05 & 0.008 & 0.210 & Confirmed \\
\hline
\end{tabular}

As we can observe from the results of Table 2, there is relatively strong relationship between gender and organizational commitment when the level of significance is five or even one percent. The positive sign shows that gender plays an important role on organizational commitment.

\subsection{Educational background and organizational commitment}

The third hypothesis of this paper is associated with the effects of educational background on organizational commitment and the results are given in Table 3.

Table 3

Pearson correlation test between educational background and organizational commitment

\begin{tabular}{llllll}
\hline $\begin{array}{l}\text { Independent } \\
\text { variable }\end{array}$ & $\begin{array}{l}\text { Dependent } \\
\text { variable }\end{array}$ & $\begin{array}{l}\text { Level of } \\
\text { significance }\end{array}$ & P-value & $\begin{array}{l}\text { Pearson canonical } \\
\text { correlation }\end{array}$ & $\begin{array}{l}\text { Results of } \\
\text { hypothesis }\end{array}$ \\
\hline $\begin{array}{l}\text { Educational } \\
\text { background }\end{array}$ & $\begin{array}{l}\text { Organizational } \\
\text { commitment }\end{array}$ & 0.05 & 0.000 & 0.600 & Confirmed \\
\hline
\end{tabular}

As we can observe from the results of Table 3, there is a strong relationship between educational background and organizational commitment when the level of significance is five or even one percent. The positive sign shows that education is an important part of creating motivation among employees for more organizational commitment. In our survey, educated people represent higher commitment towards their organizations.

\subsection{Marital status and organizational commitment}

The fourth hypothesis of this paper is associated with the impacts of educational background on organizational commitment and the results are given in Table 4.

\section{Table 4}

Pearson correlation test between marital status and organizational commitment

\begin{tabular}{lllcll}
\hline $\begin{array}{l}\text { Independent } \\
\text { variable }\end{array}$ & $\begin{array}{l}\text { Dependent } \\
\text { variable }\end{array}$ & $\begin{array}{l}\text { Level of } \\
\text { significance }\end{array}$ & P-value & $\begin{array}{l}\text { Pearson canonical } \\
\text { correlation }\end{array}$ & $\begin{array}{l}\text { Results of } \\
\text { hypothesis }\end{array}$ \\
\hline Marital status & $\begin{array}{l}\text { Organizational } \\
\text { commitment }\end{array}$ & 0.05 & 0.000 & 0.794 & Confirmed \\
\hline
\end{tabular}

As we can observe from the results of Table 4, there is a strong relationship between marital status and organizational commitment when the level of significance is five or even one percent. In other 
words, it seems that when people get married they become more conservative and try to maintain their present status in their organizations.

\subsection{Job experience and organizational commitment}

The fifth hypothesis of this paper is associated with the influence of educational background on organizational commitment and the results are given in Table 5.

\section{Table 5}

Pearson correlation test between marital status and organizational commitment

\begin{tabular}{lllcll}
\hline $\begin{array}{l}\text { Independent } \\
\text { variable }\end{array}$ & $\begin{array}{l}\text { Dependent } \\
\text { variable }\end{array}$ & $\begin{array}{l}\text { Level of } \\
\text { significance }\end{array}$ & P-value & $\begin{array}{l}\text { Pearson canonical } \\
\text { correlation }\end{array}$ & $\begin{array}{l}\text { Results of } \\
\text { hypothesis }\end{array}$ \\
\hline Job experience & $\begin{array}{l}\text { Organizational } \\
\text { commitment }\end{array}$ & 0.05 & 0.000 & 0.552 & Confirmed \\
\hline
\end{tabular}

As we can observe from the results of Table 5, there is a strong relationship between job experience and organizational commitment when the level of significance is five or even one percent. In other words, it seems that as employees gain more experiences they may receive better benefit package in their organizations, which means they will be more likely to stay in their organizations and represent more organizational commitment.

\subsection{Salary and organizational commitment}

The last hypothesis of this paper is associated with the impact of salary and benefit package on organizational commitment and the results are given in Table 6.

\section{Table 6}

Pearson correlation test between Wages and organizational commitment

\begin{tabular}{llllll}
\hline $\begin{array}{l}\text { Independent } \\
\text { variable }\end{array}$ & $\begin{array}{l}\text { Dependent } \\
\text { variable }\end{array}$ & $\begin{array}{l}\text { Level of } \\
\text { significance }\end{array}$ & P-value & $\begin{array}{l}\text { Pearson canonical } \\
\text { correlation }\end{array}$ & $\begin{array}{l}\text { Results of } \\
\text { hypothesis }\end{array}$ \\
\hline Salary & $\begin{array}{l}\text { Organizational } \\
\text { commitment }\end{array}$ & 0.05 & 0.008 & 0.262 & Confirmed \\
\hline
\end{tabular}

As we can observe from the results of Table 6, there is a strong relationship between Salary and organizational commitment when the level of significance is five or even one percent. The weak correlation shows that employees are not strongly dependent on salary for their organizational commitment.

\section{Conclusion}

In this paper, we have presented an empirical study to find the relationship between different employees' characteristics including age, gender, educational background, marital status, job experience and salary with organization commitment. The results of our survey indicate that marital status is the most influential factor on organizational commitment followed by educational background and job experience. Based on the results of this survey, we can conclude that those employees who could get more experience and maintain a good educational background will more likely to stay with a firm than young employees. 


\section{Acknowledgment}

The authors would like to thank the people who contributed to this survey by participating in our research.

\section{References}

Antonacopoulou, E.P. (2000). Reconnecting education, development training through learning: A holographic perspective. Education + Training, 42 (4/5), 255-263.

Aube, C., Rousseau.V., \& Morin, E.M. (2007). Perceived organizational support and organizational commitment The moderating effect of locus of control and work autonomy. Journal of Managerial Psychology, 22 (5), 479-495.

Bahramzadeh, H., \& Khosroabadi, S. (2012). The relationship between organizational commitment and knowledge sharing: A case study of university employee cooperation. Management Science Letters, 2(7), 2661-2666.

Freund, A., \& Carmeli, A. (2003). An empirical assessment: reconstructed model for five universal forms of work commitment. Journal of Managerial Psychology,18(7), 708-725.

Jaramillo, F., \& Nixson, R.(2005).The effect of law enforcement stress on organizational commitment. An International Journal of Police Strategic and Management, 28, 321-336.

Kahn, R.L., Wolfe, D.M., Quinn, R.P., Snoek, J.D., \& Rosenthal, R.A. (1964). Organizational stress: Studies in role conflict and ambiguity. New York: John Wiley \& Sons Inc.

Katz, D., \& Kahn, R.L. (1978). The Social Psychology of Organization. New York: John Wiley \& Sons Inc.

McCabe, T.J., \& Garavan, T.N. (2008). A study of the drivers of commitment amongst nurses The salience of training, development and career issues. Journal of European Industrial Training, 32 (7), 528-568.

Mirabizadeh, M., \& Gheitasi, S. (2012). Examining the organizational citizenship behavior as the outcome of organizational commitment: Case study of universities in Ilam. Management Science Letters, 2(3), 951-960.

Nazeri, A., Meftahi, M., \& Kianipour, R. (2012). Relationship between welfare staff and organizational commitment in the control center of the Central Registration Office. Management Science Letters, 2(5), 1779-1784.

Naderi Anari, N. (2012). Teachers: emotional intelligence, job satisfaction, and organizational commitment. Journal of Workplace Learning, 24(4), 256 - 269

Pleck, J. H., Staines, G., \& Lang, L. (1980). Conflicts between work and family life. Monthly Labors Review, 29-32.

Schwartz, D.B. (1996). The impact of work-family policies on women's career development: boon or bust?. Women in Management Review, 11(1), 5-19. 